\title{
Studies on Interaction Effects of Combined Application of Magnesium and Potassium on Soil Properties and Yield of Tomato (Solanum lycopersicum L.) in an Alfisol
}

\section{B.L. Kasinath ${ }^{1}$, A.N. Ganeshmurthy ${ }^{2}$, T. Senthivel ${ }^{3}$, M. Senthil Kumar ${ }^{2 *}$, B.L. Manjunath ${ }^{2}$ and A.T. Sadashiva ${ }^{2}$}

${ }^{1}$ ICAR-Central Island Agricultural Research Institute, Port Blair, A \& N Islands, India

${ }^{2}$ ICAR-Indian Institute of Horticultural Research Institute, Hesaragatta, Bengaluru, India

${ }^{3}$ Ghandigram Rural Institute, Dindugal, Tamilnadu, India

*Corresponding author

\section{A B S T R A C T}

\begin{tabular}{|l|}
\hline Key w or d s \\
Magnesium, \\
Potassium, \\
Synergistic, \\
Interaction, \\
Antagonism and \\
deficiency.
\end{tabular}

A field experiment was conducted at ICAR-Indian Institute of Horticultural Research, Bengaluru to assess the interaction effects of combined application of Magnesium $(\mathrm{Mg})$ and Potassium $(\mathrm{K})$ on soil properties and yield of tomato. Results showed that mean effect of applied $\mathrm{Mg}$ resulted in 23 per cent to 28 per cent higher yield up to a doze of $50 \mathrm{~kg} \mathrm{Mg}$ $\mathrm{ha}^{-1}$ as compared to non-application of magnesium. The application of $\mathrm{K}$ also significantly influenced the yield. The dose of $100 \mathrm{~kg} \mathrm{~K} \mathrm{ha}^{-1}$ along with $50 \mathrm{~kg} \mathrm{Mg} \mathrm{ha}^{-1}$ recorded the highest yield of $84.39 \mathrm{~kg} \mathrm{ha}^{-1}$ which was 13 per cent higher compared to non-application of $\mathrm{K}$. Graded levels of $\mathrm{Mg}$ and $\mathrm{K}$ did not have any significant effect on either soil $\mathrm{pH}, \mathrm{EC}$ and OC. Application of $\mathrm{Mg}$ and $\mathrm{K}$ did not have any significant influence on soil available $\mathrm{N}$. With an increase in the applied Mg levels, the mean available $\mathrm{N}$ content decreased. The results showed that with the increase in the applied Mg levels the mean available P content decreased upto 5 per cent. Similarly, the application of $\mathrm{Mg}$ and $\mathrm{K}$ together significantly had negative influence on soil available $\mathrm{K}$ and $\mathrm{Ca}$. The mean available $\mathrm{K}$ content decreased with the increase of $\mathrm{Mg}$ level. These results indicated the existence of antagonism among $\mathrm{Mg}, \mathrm{K}$ and $\mathrm{Ca}$ in the soil. Hence, when the soil is deficient in $\mathrm{K}$ and $\mathrm{Mg}$, the deficiency of $\mathrm{Mg}$ should be corrected before applying $\mathrm{K}$ fertilizer for achieving higher yields.

\section{Introduction}

Tomato is one of the important vegetables grown throughout the world under open and controlled conditions. India produces 18.74 million tonnes of tomato from an area of 8.82 lakh hectares. The average productivity is $21.2 \mathrm{t} \mathrm{ha}^{-1}$ (NHB-2014). It serves as a daily component of diet in many countries and also an important source of minerals, vitamins and antioxidants (Grienrson and Kader, 1986).
It is rich in calories and vitamins A, B and C and a good source of Iron. Consumption of $230 \mathrm{~g}$ of tomato can supplement daily requirement of vitamin $\mathrm{C}$ in adults and reduce the risk of developing colon, rectal and stomach cancer.

The steady increase in the population will intensify the use of natural resources such as 
land, water and air for achieving higher food production which is only possible by increasing the productivity per unit area by way of development of high yielding varieties/hybrids clubbed with intensive production practices. One of the primary causes of low productivity is the imbalanced use of plant nutrients which lead to soil mining and depletion of mineral elements in soils (Ganeshamurthy and Hegde, 1980). In India, the deficiency of secondary and micro nutrients increased with application of only $\mathrm{N}$, $\mathrm{P}$ and $\mathrm{K}$ fertilizers, ignoring secondary and micronutrients (Shukla et al., 2009) and application of $\mathrm{N}$ alone increased soil depletion of other nutrients including $\mathrm{Ca}, \mathrm{Mg}$ and S (Nambiar and Abrol, 1989). Among the secondary nutrients, $\mathrm{Mg}$ plays a vital role in the formation of chlorophyll (as it contains about seven per cent of magnesium), fat, vitamins, amino acids and also involves in many biochemical and physiological functions including transport of phosphates, and phosphorylating enzyme in carbohydrate metabolism. It also influences earliness, ensures uniform maturity and improves the quality of fruits (Ganeshamurthy and Hegde, 1980).The important interactions of $\mathrm{K}, \mathrm{Ca}$ and $\mathrm{Mg}$ in a soil or nutrient media play each other antagonistically in uptake of these elements by plants. As reported by Ananthanarayana and Hanumantharaju (1992), antagonism between $\mathrm{Mg}$ and $\mathrm{K}$ could be the differences in their ionic mobility. High $\mathrm{K}$ concentration in nutrient solution resulted in $\mathrm{Mg}$ deficiency in plant tissue (Jones, 1999) and vice-versa. The correct ratio of $\mathrm{K}$ and $\mathrm{Mg}$ in the soil is important because of excessive concentrations of either of the elements can negatively affect the plant growth (Bergmann, 1992). In Tomato $\mathrm{Mg}, \mathrm{K}$ and $\mathrm{Ca}$ play a vital role in nutrition management and strongly interfere with each other in absorption mechanism of the plants (Hao and Papadopoulas, 2003). The ideal base saturation of cations $\mathrm{Ca}, \mathrm{Mg}, \mathrm{K}$ and $\mathrm{H}$ in the exchange complex is $40-50,5-15,2-$
5 and 20-30 per cent respectively. Deficiency of these elements occurs due to under supply or antagonistic effect on each other thus decrease the yield and quality of tomato. When $\mathrm{Mg}$ level was high, a high level of $\mathrm{K}$ was effective in reducing $\mathrm{Mg}$ content of spinach, but there was no effect when $\mathrm{Mg}$ level was low (Hohlt and Maynard, 1966). This suggests that cation interaction is more intense at high concentrations as compared to low ones. Antagonism between $\mathrm{K}$ and $\mathrm{Mg}$ was observed (Kolota and Orlowski, 1984) in tomato and the results showed that good plant growth and highest yields were obtained from the plants receiving $\mathrm{K}_{2} \mathrm{O}$ and $\mathrm{Mg}$ each at 400 $\mathrm{Mg}^{-1}$ soil. Adams et al., (1978) studied tomato yield in relation to the $\mathrm{N}, \mathrm{K}$ and $\mathrm{Mg}$ status of the plants and of the peat substrate. Maximum yields were obtained when the nutrient content in leaves was 4.5-5.1 per cent $\mathrm{N}$, 4.4-5.6 per cent $\mathrm{K}$ and $0.31-0.40$ per cent $\mathrm{Mg}$. It was found that $\mathrm{Mg}$ content of $250 \mathrm{Mg}$ $1^{-1}$ was fully adequate for obtaining optimum yields. $\mathrm{Mg}$ and $\mathrm{K}$ interactions in plant and soils were studied by Ananthanarayana and Venkata Rao (1979) in pea crop. They found significant variations among different treatments in yield with increasing levels of $\mathrm{Mg}$. It is paradoxical in the sense that on one hand application of $\mathrm{K}$ fertilizer increases the yield and also has antagonistic effect on $\mathrm{Mg}$ uptake. In tomato, Kolota and Orlwski (1984) observed antagonism between $\mathrm{K}$ and $\mathrm{Mg}$ at higher potassium rates. Therefore, in soil deficient in $\mathrm{K}$ and $\mathrm{Mg}$, the deficiency of $\mathrm{Mg}$ should be corrected before applying $\mathrm{K}$ fertilizer.

Generally, $\mathrm{Mg}$ deficiency in plants will be noticed in older leaves. The leaves become abnormal and an inter-venal chlorosis starts on the lower leaves of plant. In advanced stage, the colour of leaves becomes purplish red; leaves become brittle with a tendency to curve upward. In these crops, twigs remain weak, and shed prematurely. The critical limit 
in plant is 0.1 to 0.2 per cent of $\mathrm{Mg}$ in terms of plant dry matter. For a healthy tomato leaf, the $\mathrm{Mg}$ concentration should be from 0.40 to 0.60 per cent (Ward and Miller, 1969).

In order to obtain higher yield with good fruit quality $\mathrm{K}, \mathrm{Mg}$ and $\mathrm{Ca}$ nutrients must be made available in sufficient quantity in proper ratio. These important cations strongly interact with each other and excess of one element induces deficiency of another element. Thus good nutrition management is required to make these elements available in sufficient quantity in nutrient solution for obtaining higher yield in tomatoes with quality. Hence an attempt was made through this study to assess the interaction effects of combined application of Magnesium and Potassium on soil properties and yield of tomato.

\section{Materials and Methods}

The study was conducted at ICAR-Indian Institute of Horticultural Research, Hesaraghatta, Bengaluru, during the rabi of 2011-12. The Initial soil-chemical properties and nutrient status in the experimental site were: $\mathrm{pH}-6.14$, EC- $0.74 \mathrm{dsm}^{-1}$, OC- $0.74, \mathrm{~N}$ 119.88 ppm, P- 3.51 ppm, K- 731.20ppm, Ca$158 \mathrm{ppm}$ and $\mathrm{Mg}-61.6 \mathrm{ppm}$. The experiment was laid out in a Split plot design, with 12 treatments (four main plot treatments for magnesium and three sub plot treatments for potassium) and three replications.

\section{Fertilizer application}

The recommended dose of fertilizer (RDF) for tomato, 180:150:120 kg NPK kg ha ${ }^{-1}$, was applied to all the treatments in the form of urea, Diammonium phosphate (DAP) and muriate of potash. The quantity of urea $263.71 \mathrm{~kg} \mathrm{ha}^{-1}$, DAP-(18:46:0) $326.08 \mathrm{~kg} \mathrm{ha}^{-1}$ and muriate of potash-200 kg ha ${ }^{-1}$ were applied through soil application. Full dose of $\mathrm{P}$ and $\mathrm{K}$ was applied as soil application whereas, Nitrogen was applied in three splits, viz., 50\% RDF at planting, 25\% RDF each at 25 days after transplanting and 50 days after transplanting. Magnesium was applied as basal dose in the form of magnesium sulphate $\left(\mathrm{MgSO}_{4} .7 \mathrm{H}_{2} \mathrm{O}\right)$. The quantity of magnesium was applied in the form of magnesium sulphate. The treatment details are given in table 1 .

Tomato hybrid Arka Ananya of ICAR-Indian Institute of Horticultural Research was transplanted at a spacing of $100 \mathrm{~cm} \times 60 \mathrm{~cm}$. Fruits were harvested in 10 pickings, and weight of the fruits from each plant was recorded separately for obtaining fruit yield $(\mathrm{t}$ $\left.\mathrm{ha}^{-1}\right)$. Soil samples were collected at three stages of crop for analysing $\mathrm{pH}, \mathrm{EC}, \mathrm{OC}$ and at the end of cropping period for $\mathrm{N}, \mathrm{P}, \mathrm{K}, \mathrm{Ca}$ and $\mathrm{Mg}$. Standard analytical methods were followed for the analysis of soil samples. The data on yield and other soil parameters were tabulated and statistical analysis was done as per the methods suggested by Sundaraja et al., (1972).

\section{Results and Discussion}

\section{Fruit Yield}

The data pertaining to yield of tomato hybrid as influenced by four levels of $\mathrm{Mg}$ and three levels of $\mathrm{K}$ and their interaction is presented in table 2. Application of $\mathrm{Mg}$ and $\mathrm{K}$ produced significant treatment differences in the yield. The mean effect of applied $\mathrm{Mg}$ resulted in increasing the yield of tomato up to $50 \mathrm{~kg} \mathrm{Mg}$ $\mathrm{ha}^{-1}$. The lowest mean yield of $63.38 \mathrm{t} \mathrm{ha}^{-1}$ was observed in the plots where $\mathrm{Mg}$ was not applied $\operatorname{Mg}_{1}\left(0 \mathrm{~kg} \mathrm{Mg} \mathrm{ha}{ }^{-1}\right)$, on the other hand the highest mean yield of $80.46 \mathrm{t} \mathrm{ha}^{-1}$ was obtained through application of $\mathrm{Mg}_{2}(50 \mathrm{~kg}$ $\mathrm{Mg} \mathrm{ha} \mathrm{h}^{-1}$ ). The application of $\mathrm{K}$ produced significant change in the yield. At lower levels of applied $\mathrm{K}$, the mean yield of tomato increased up to $100 \mathrm{~kg} \mathrm{~K} \mathrm{ha}^{-1}$ and decreased 
at higher levels beyond $100 \mathrm{~kg} \mathrm{~K} \mathrm{ha}{ }^{-1}$. The lowest mean yield of $69.06 \mathrm{t} \mathrm{ha}^{-1}$ was obtained at $\mathrm{K}_{1}\left(0 \mathrm{~kg} \mathrm{~K} \mathrm{ha}^{-1}\right)$ and the highest yield of $75.48 \mathrm{t} \mathrm{ha}^{-1}$ was obtained at $\mathrm{K}_{2}(100$ $\left.\mathrm{kg} \mathrm{K} \mathrm{ha}{ }^{-1}\right)$. The interaction effect of $\mathrm{Mg}$ and $\mathrm{K}$ on yield showed that a combination of $\mathrm{Mg}_{2}$ $\left(50 \mathrm{~kg} \mathrm{Mg} \mathrm{ha}^{-1}\right)$ with $\mathrm{K}_{2}\left(100 \mathrm{~kg} \mathrm{~K} \mathrm{ha}^{-1}\right)$ resulted in highest yield $\left(84.39 \mathrm{tha}^{-1}\right)$ and the combination of $\mathrm{Mg}_{1}\left(0 \mathrm{~kg} \mathrm{ha}^{-1}\right)$ with $\mathrm{K}_{1}(0 \mathrm{~kg}$ $\mathrm{K} \mathrm{ha}^{-1}$ ) given the lowest yield of $57.71 \mathrm{t}$ ha ${ }^{1}$.The important interactions of $\mathrm{K}, \mathrm{Ca}$ and $\mathrm{Mg}$ in a soil or nutrient media were antagonistic to each other in uptake of these elements by plants. As reported by Ananthanarayana and Hanumantharaju (1992), antagonism between $\mathrm{Mg}$ and $\mathrm{K}$ could be due to the differences in their ionic mobility. High $\mathrm{K}$ concentration in nutrient solution resulted in Mg deficiency in plant tissue (Jones, 1999) and vice-versa. The correct proportion of $\mathrm{K}: \mathrm{Mg}$ in the soil is important because of excessive concentrations of either element can negatively affect the plant growth (Bergmann, 1992). Sonneveld (1987) observed that in rockwool grown tomato, the Mg deficiency symptoms reduced due to high and low $\mathrm{K} / \mathrm{Ca}$ elements in the nutrient solution. A high $\mathrm{K}$ level was effective in reducing $\mathrm{Mg}$ content of spinach when $\mathrm{Mg}$ level was high, but no effect when Mg level was low (Hohlt and Maynard, 1966) this suggests that cation interaction was more intense at high concentrations than at low ones. Antagonism between $\mathrm{K}$ and $\mathrm{Mg}$ was observed (Kolota and Orlowski, 1984) in tomato. Good plant growth and highest yields were obtained from the plants applied with $\mathrm{K}_{2} \mathrm{O}$ and $\mathrm{Mg}$ each at $400 \mathrm{Mgl}^{-1}$ soil. Good nutritional status was observed when leaf contents of $\mathrm{Mg}$ and $\mathrm{K}$ were 0.59 and 4.67 per cent respectively. In corn as observed by Foy and Barber (1958), Mg additions essentially prevented the $\mathrm{Mg}$ deficiency symptoms, significantly increased the percentage of $\mathrm{Mg}$ and reduced the percentage of $\mathrm{K}$ in leaves. Adams et al., (1978) studied tomato yield in relation to the $\mathrm{N}, \mathrm{K}$ and $\mathrm{Mg}$ status of the plants and of the peat substrate. Maximum yields were obtained when the nutrient content in leaves was $4.5-5.1$ per cent $\mathrm{N}$, 4.4-5.6 percent $\mathrm{K}$ and $0.31-0.40$ percent $\mathrm{Mg}$. It was found that $\mathrm{Mg}$ content of $250 \mathrm{Mg} \mathrm{l}^{-1}$ was fully adequate for obtaining optimum yields. $\mathrm{K}$ and $\mathrm{Mg}$ have antagonistic relations with respect to availability of one over the other and their effect on crop performance. This study revealed that combined application of $50 \mathrm{~kg} \mathrm{Mg} \mathrm{ha}{ }^{-1}$ and $100 \mathrm{~kg} \mathrm{~K} \mathrm{ha}^{-1}$ is the optimum level for these nutrients for achieving higher yield.

\section{Interaction effect of applied $\mathrm{Mg}$ and $\mathrm{K}$ on Soil pH and EC}

The data pertaining to Soil $\mathrm{pH}$ and $\mathrm{EC}$ as influenced by four levels of $\mathrm{Mg}$ and three levels of $\mathrm{K}$ and their interaction is shown in Fig. 1 and 2 respectively. The application of $\mathrm{Mg}$ and $\mathrm{K}$ did not induce any significant change in soil $\mathrm{pH}$ and $\mathrm{EC}$. The interaction effect of combined application of $\mathrm{Mg}\left(\mathrm{Mg}_{1-} \mathrm{O}\right.$ $\left.\mathrm{kg} \mathrm{Mg} \mathrm{ha}{ }^{-1}\right)$ and $\mathrm{K}\left(\mathrm{K}_{3}-250 \mathrm{~kg} \mathrm{~K} \mathrm{ha}^{-1}\right)$ resulted in the lowest soil $\mathrm{pH}$ of 5.81 and the highest soil $\mathrm{pH}$ value 5.85 was obtained at the combination of $\mathrm{Mg}_{4}\left(250 \mathrm{~kg} \mathrm{Mg} \mathrm{ha}^{-1}\right)$ and $\mathrm{K}_{1}$ $\left(0 \mathrm{~kg} \mathrm{~K} \mathrm{ha}^{-1}\right)$. The lowest soil EC value 0.38 $\mathrm{dSm}^{-1}$ was observed at the combined application of $\mathrm{Mg}_{1}\left(0 \mathrm{~kg} \mathrm{Mg} \mathrm{ha}{ }^{-1}\right)$ and $\mathrm{K}_{1}(0$ $\mathrm{kg} \mathrm{K} \mathrm{ha}{ }^{-1}$ ) and the highest soil EC of 0.43 $\mathrm{dSm}^{-1}$ was obtained at the combined application of $\mathrm{Mg}_{4}\left(250 \mathrm{~kg} \mathrm{Mg} \mathrm{ha}{ }^{-1}\right)$ with $\mathrm{K}_{3}$ $\left(250 \mathrm{~kg} \mathrm{~K} \mathrm{ha}^{-1}\right), \mathrm{Mg}_{4}\left(250 \mathrm{~kg} \mathrm{Mg} \mathrm{ha}^{-1}\right)$ with $\mathrm{K}_{2}\left(100 \mathrm{~kg} \mathrm{~K} \mathrm{ha}^{-1}\right)$ and $\mathrm{Mg}_{4}\left(250 \mathrm{~kg} \mathrm{Mg} \mathrm{ha}^{-1}\right)$ with $\mathrm{K}_{3}\left(250 \mathrm{~kg} \mathrm{~K} \mathrm{ha}^{-1}\right)$. This is because; the levels of both $\mathrm{Mg}$ and $\mathrm{K}$ used in this study were small to cause any effect on $\mathrm{pH}$ and $\mathrm{EC}$. It is expected that with increased levels of applied $\mathrm{Mg}$ and $\mathrm{K}$ the soil $\mathrm{pH}$ and $\mathrm{EC}$ should show an increase. Present study also indicated this trend, although the results were not statistically significant. Most of the tomato studies revealed that increasing electrical conductivity (EC) of the nutrient solution 
improves fruit quality (Adams, 1991; Gough and Hobson, 1990) and increases shelf life. Mizrahi and Mizrahi (1982) studied the effect of potassium magnesium chloride in the fertigation solution as partial source of potassium on growth, yield and quality of green house tomato, the study revealed that the fertigation of $\mathrm{Kcl}^{-\mathrm{MgCl}_{2}}$ increased the yield of tomato.

\section{Interaction effect of applied $\mathrm{Mg}$ and $\mathrm{K}$ on soil OC and Soil N}

The application of $\mathrm{Mg}$ and $\mathrm{K}$ did not result in significant change in soil organic carbon and Soil Nitrogen. The highest soil OC mean value of 0.68 per cent was obtained at combined application of $\mathrm{Mg}_{3}\left(100 \mathrm{~kg} \mathrm{ha}^{-1}\right)$ with $\mathrm{K}_{2}\left(100 \mathrm{~kg} \mathrm{ha}^{-1}\right), \mathrm{Mg}_{3}\left(100 \mathrm{~kg} \mathrm{Mg} \mathrm{ha}{ }^{-1}\right)$ with $\mathrm{K}_{3}\left(250 \mathrm{~K} \mathrm{~kg} \mathrm{ha}^{-1}\right)$ and $\mathrm{Mg}_{4}(250 \mathrm{~kg} \mathrm{Mg}$ $\left.\mathrm{ha}^{-1}\right)$ with $\mathrm{K}_{1}\left(0 \mathrm{~kg} \mathrm{~K} \mathrm{ha}^{-1}\right)$ and the lowest soil organic carbon of 0.64 per cent was observed at combined application of $\operatorname{Mg}_{1}\left(0 \mathrm{~kg} \mathrm{Mg} \mathrm{ha}{ }^{-1}\right)$ with $\mathrm{K}_{1}\left(0 \mathrm{~K} \mathrm{~kg} \mathrm{ha}^{-1}\right)$.

This might be due to the fact that the biomass production increased with application of desired levels of $\mathrm{Mg}$ and $\mathrm{K}$ but the effect on soil organic carbon could not be seen as the time was too short to obtain any such changes in soil organic carbon particularly in tropical soils like those under this experimentation.

The application of $\mathrm{Mg}$ and $\mathrm{K}$ did not have any significant influence on soil available $\mathrm{N}$. It was also observed that, the increase in the $\mathrm{Mg}$ levels decreased the mean value of available $\mathrm{N}$. As the level of applied $\mathrm{K}$ increased, the available $\mathrm{N}$ content remained at $124 \mathrm{~kg} \mathrm{~N}$ $\mathrm{ha}^{-1}$. The combined application of $\mathrm{Mg}\left(\mathrm{Mg}_{4}\right.$ $\left.250 \mathrm{~kg} \mathrm{Mg} \mathrm{ha}{ }^{-1}\right)$ and $\mathrm{K}\left(\mathrm{K}_{1} \quad .0 \mathrm{~kg} \mathrm{~K} \mathrm{ha}{ }^{-1}\right)$ resulted in lowest available $\mathrm{N}(123.60 \mathrm{~kg} \mathrm{~N}$ $\mathrm{ha}^{-1}$ ) and the highest value of $126.23 \mathrm{~kg} \mathrm{~N}$ ha ${ }^{1}$ was observed at the combination of $\mathrm{Mg}_{2}(50$ $\left.\mathrm{kg} \mathrm{Mg} \mathrm{ha}{ }^{-1}\right)$ with $\mathrm{K}_{3}\left(250 \mathrm{~kg} \quad \mathrm{~K} \quad \mathrm{ha}^{-1}\right)$. Subramanian et al., (1976) reported an increase not only in the uptake of $\mathrm{N}$ and $\mathrm{P}$ and but also the yield of groundnut. Adams et al., (1978) reported maximum yield of tomato when the nutrient content in leaves was 4.5 5.1 per cent $\mathrm{N}, 4.4-5.6$ per cent $\mathrm{K}$ and 0.310.40 per cent $\mathrm{Mg}$. They found that $\mathrm{Mg}$ content of $250 \mathrm{mg} \mathrm{l}^{-1}$ was very much adequate for obtaining optimum yields (Table 3).

\section{Soil $\mathbf{P}$ and Soil $\mathrm{K}$}

The combined application of four levels of $\mathrm{Mg}$ and three levels of $\mathrm{K}$ significantly influenced the soil available phosphorus and potassium content (Table 4). With the increase in the applied Mg levels, the mean available $\mathrm{P}$ content decreased from 7.84 (control $-0 \mathrm{~kg}$ $\left.\mathrm{Mg} \mathrm{ha}^{-1}\right)$ to $7.46 \mathrm{~kg} \mathrm{P} \mathrm{ha}^{-1}\left(\mathrm{Mg}_{4}-250 \mathrm{~kg} \mathrm{Mg}\right.$ $\mathrm{ha}^{-1}$ ). As the level of applied $\mathrm{K}$ increased, the available $\mathrm{P}$ content increased from 7.57 to $7.76 \mathrm{~kg} \mathrm{P} \mathrm{ha}^{-1}$. Interaction effects of applied $\mathrm{Mg}$ and $\mathrm{K}$ resulted in decrease of soil available $\mathrm{P}$ from $7.81 \mathrm{~kg} \mathrm{P} \mathrm{ha}^{-1}$ at the combination of $\operatorname{Mg}_{1}\left(0 \mathrm{~kg} \mathrm{Mg} \mathrm{ha}^{-1}\right)$ with $\mathrm{K}_{1}(0$ $\left.\mathrm{kg} \mathrm{K} \mathrm{ha}{ }^{-1}\right)$ to $7.34 \mathrm{~kg}^{-1} \mathrm{P} \mathrm{ha}^{-1}$ at $\mathrm{Mg}_{4}(250 \mathrm{~kg}$ $\left.\mathrm{Mg} \mathrm{ha}^{-1}\right)$ with $\mathrm{K}_{1}\left(0 \mathrm{~kg} \mathrm{~K} \mathrm{ha}^{-1}\right)$.

This showed that the $\mathrm{Mg}$ has synergistic reaction with $\mathrm{P}$ upto certain level hence the results showed that the available $\mathrm{P}$ content increased as the level of $\mathrm{Mg}$ increased upto 50 $\mathrm{kg} \mathrm{Mg} \mathrm{ha}{ }^{-1}$ thereafter started decreasing. In general it was observed that mean soil $\mathrm{P}$ content increased with the increase in level of application of $\mathrm{Mg}$ and $\mathrm{K}$ to the soil. Subramanian et al., (1976) showed that as the level of $\mathrm{Mg}$ is increased the uptake of $\mathrm{N}$ and $\mathrm{P}$ increased the yield in groundnut.

According to Bergman (1992) high K indirectly causes damage to plants growth by inducing $\mathrm{Ca}$ and $\mathrm{Mg}$ deficiencies. The mean available $\mathrm{K}$ content decreased with an increase of application of $\mathrm{Mg}$. As the level of applied $\mathrm{K}$ increased the available $\mathrm{K}$ content also increased. 
Table.1 Treatment details of magnesium and potassium interaction experiment

\begin{tabular}{|c|c|c|c|c|c|}
\hline Treatment & $\begin{array}{c}\text { RDF } \\
\mathbf{N}: \mathbf{P}_{2} \mathbf{O}_{5}: \mathbf{K}_{2} \mathbf{O} \mathbf{~ k g} \\
\text { ha }^{-1}\end{array}$ & $\operatorname{Mg}\left(\mathrm{kg} \mathrm{ha}^{-1}\right)$ & $\begin{array}{c}\text { Equivalent } \\
\text { quantity of } \\
\mathrm{MgSO}_{4}\left(\mathrm{~kg} \mathrm{ha}^{-1}\right) \\
\text { applied } \\
\end{array}$ & $\mathrm{K}_{2} \mathrm{O}\left(\mathrm{kg} \mathrm{ha}^{-1}\right)$ & $\begin{array}{c}\text { Equivalent } \\
\text { quantity of } \\
\text { MOP }\left(\mathrm{kg} \mathrm{ha}^{-1}\right) \\
\text { applied } \\
\end{array}$ \\
\hline $\mathrm{T}_{1}$ & 180:150:120 & 0 & 0 & 0 & 0 \\
\hline $\mathrm{T}_{2}$ & 180:150:120 & 0 & 0 & 100 & 166.66 \\
\hline $\mathrm{T}_{3}$ & 180:150:120 & 0 & 0 & 250 & 416.66 \\
\hline $\mathrm{T}_{4}$ & 180:150:120 & 50 & 514 & 0 & 0 \\
\hline $\mathrm{T}_{5}$ & 180:150:120 & 50 & 514 & 100 & 166.66 \\
\hline $\mathrm{T}_{6}$ & 180:150:120 & 50 & 514 & 250 & 416.66 \\
\hline $\mathrm{T}_{7}$ & 180:150:120 & 100 & 1028 & 0 & 0 \\
\hline $\mathrm{T}_{8}$ & 180:150:120 & 100 & 1028 & 100 & 166.66 \\
\hline $\mathrm{T}_{9}$ & 180:150:120 & 100 & 1028 & 250 & 416.66 \\
\hline $\mathrm{T}_{10}$ & 180:150:120 & 250 & 2570 & 0 & 0 \\
\hline $\mathrm{T}_{11}$ & 180:150:120 & 250 & 2570 & 100 & 166.66 \\
\hline $\mathrm{T}_{12}$ & 180:150:120 & 250 & 2570 & 250 & 416.66 \\
\hline
\end{tabular}

Table.2 Tomato (Arka Ananya) yield $\left(\mathrm{t} \mathrm{ha}^{-1}\right)$ as influenced by interaction effect of $\mathrm{Mg}$ with potassium

\begin{tabular}{|c|c|c|c|c|}
\hline \multirow[b]{2}{*}{ Treatments } & \multicolumn{4}{|c|}{ Yield $\left(\mathrm{t} \mathrm{ha}^{-1}\right)$} \\
\hline & $\begin{array}{c}\mathbf{K}_{1} \\
\left(0 \mathrm{~kg}^{2}\right. \\
\left.\mathrm{K}^{-1-1}\right)\end{array}$ & $\begin{array}{c}\mathrm{K}_{2} \\
\left(100 \mathrm{~kg}^{2}\right. \\
\left.\mathrm{K} \mathrm{ha}^{-1}\right)\end{array}$ & $\begin{array}{c}\mathrm{K}_{3} \\
(250 \mathrm{~kg} \\
\left.\mathrm{K} \mathrm{ha}^{-1}\right)\end{array}$ & Mean \\
\hline $\operatorname{Mg}_{1}\left(0 \mathrm{~kg} \mathrm{Mg} \mathrm{ha}^{-1}\right)$ & 57.71 & 66.23 & 66.19 & 63.38 \\
\hline $\operatorname{Mg}_{2}\left(50 \mathrm{~kg} \mathrm{Mg} \mathrm{ha}^{-1}\right)$ & 74.15 & 84.39 & 82.85 & 80.46 \\
\hline $\operatorname{Mg}_{3}\left(100 \mathrm{~kg} \mathrm{Mg} \mathrm{ha}^{-1}\right)$ & 73.64 & 79.31 & 69.01 & 73.99 \\
\hline $\operatorname{Mg}_{4}\left(250 \mathrm{~kg} \mathrm{Mg} \mathrm{ha}^{-1}\right)$ & 70.73 & 71.97 & 64.84 & 69.18 \\
\hline \multirow[t]{2}{*}{ Mean } & 69.06 & 75.48 & 70.72 & 71.75 \\
\hline & \multicolumn{2}{|c|}{ S. Em \pm} & \multicolumn{2}{|c|}{ C.D at 5\% } \\
\hline Mg & \multicolumn{2}{|c|}{2.194} & \multicolumn{2}{|c|}{7.593} \\
\hline K & \multicolumn{2}{|c|}{1.244} & \multicolumn{2}{|c|}{3.731} \\
\hline $\operatorname{Mg} \times \mathbf{K}$ & \multicolumn{2}{|c|}{2.489} & \multicolumn{2}{|c|}{7.463} \\
\hline
\end{tabular}

Table.3 Interaction effects of applied $\mathrm{Mg}$ and $\mathrm{K}$ on soil organic carbon (\%) and soil nitrogen $\left(\mathrm{kg} \mathrm{ha}^{-1}\right)$

\begin{tabular}{|c|c|c|c|c|c|c|c|c|}
\hline \multirow[b]{2}{*}{ Treatment } & \multicolumn{4}{|c|}{ Organic Carbon (\%) } & \multicolumn{4}{|c|}{ Soil Nitrogen $\left(\mathrm{kg} \mathrm{ha}^{-1}\right)$} \\
\hline & $\begin{array}{c}\mathbf{K}_{1} \\
(0 \mathrm{~kg} \\
\left.\mathrm{K} \mathrm{ha}^{-1}\right)\end{array}$ & $\begin{array}{c}\mathrm{K}_{2} \\
(100 \mathrm{~kg} \\
\left.\mathrm{K} \mathrm{ha}^{-1}\right)\end{array}$ & $\begin{array}{c}\mathrm{K}_{3} \\
(250 \mathrm{~kg} \\
\left.\mathrm{K} \mathrm{ha}^{-1}\right)\end{array}$ & Mean & $\begin{array}{c}\mathbf{K}_{1} \\
(0 \mathrm{~kg} \\
\left.\mathrm{K} \mathrm{ha}^{-1}\right)\end{array}$ & $\begin{array}{c}\mathbf{K}_{2} \\
(100 \mathbf{~ k g} \\
\left.\mathrm{K} \mathrm{ha}^{-1}\right)\end{array}$ & $\begin{array}{c}\mathbf{K}_{3} \\
\left(250 \mathrm{~kg}^{2}\right. \\
\left.\mathrm{K} \mathrm{h}^{-1}\right)\end{array}$ & Mean \\
\hline $\operatorname{Mg}_{1}\left(0 \mathrm{~kg} \mathrm{Mg} \mathrm{ha}^{-1}\right)$ & 0.64 & 0.67 & 0.67 & 0.66 & 125.29 & 123.82 & 124.24 & 124.45 \\
\hline $\operatorname{Mg}_{2}\left(50 \mathrm{~kg} \mathrm{Mg} \mathrm{ha}^{-1}\right)$ & 0.65 & 0.66 & 0.67 & 0.66 & 124.60 & 125.36 & 126.23 & 125.40 \\
\hline $\mathrm{Mg}_{3}\left(100 \mathrm{~kg} \mathrm{Mg} \mathrm{ha}^{-1}\right)$ & 0.67 & 0.66 & 0.68 & 0.67 & 125.11 & 125.59 & 123.98 & 124.89 \\
\hline $\mathrm{Mg}_{4}\left(250 \mathrm{~kg} \mathrm{Mg} \mathrm{ha}^{-1}\right)$ & 0.68 & 0.67 & 0.68 & 0.68 & 123.60 & 124.74 & 124.32 & 124.23 \\
\hline \multirow[t]{2}{*}{ Mean } & 0.66 & 0.67 & 0.68 & & 124.65 & 124.88 & 124.69 & \\
\hline & \multicolumn{2}{|c|}{ S. Em \pm} & \multicolumn{2}{|c|}{ C.D at $5 \%$} & \multicolumn{2}{|c|}{ S. Em \pm} & \multicolumn{2}{|c|}{ C.D at $5 \%$} \\
\hline Mg & \multicolumn{2}{|c|}{ NS } & \multicolumn{2}{|c|}{ NS } & \multicolumn{2}{|c|}{ NS } & \multicolumn{2}{|c|}{ NS } \\
\hline $\mathbf{K}$ & \multicolumn{2}{|c|}{ NS } & \multicolumn{2}{|c|}{ NS } & \multicolumn{2}{|c|}{ NS } & \multicolumn{2}{|c|}{ NS } \\
\hline $\operatorname{Mg} \times \mathbf{K}$ & \multicolumn{2}{|c|}{ NS } & \multicolumn{2}{|c|}{ NS } & \multicolumn{2}{|c|}{ NS } & \multicolumn{2}{|c|}{ NS } \\
\hline
\end{tabular}


Table.4 Interaction effects of applied $\mathrm{Mg}$ and $\mathrm{K}$ on soil phosphorus and potassium

\begin{tabular}{|c|c|c|c|c|c|c|c|c|}
\hline \multirow[b]{2}{*}{ Treatment } & \multicolumn{4}{|c|}{ Soil Phosphorus (kg ha ${ }^{-1}$ ) } & \multicolumn{4}{|c|}{ Soil Potassium $\left(\mathrm{kg} \mathrm{ha}^{-1}\right)$} \\
\hline & $\begin{array}{c}\mathbf{K}_{1} \\
(0 \mathrm{~kg} \\
\left.\mathrm{K}^{-1} \mathbf{h a}^{-1}\right)\end{array}$ & $\begin{array}{c}\mathrm{K}_{2} \\
(100 \mathrm{~kg} \\
\left.\mathrm{K} \mathrm{ha}^{-1}\right) \\
\end{array}$ & $\begin{array}{c}\mathrm{K}_{3} \\
(250 \mathrm{~kg} \\
\left.\mathrm{K} \mathrm{ha}^{-1}\right) \\
\end{array}$ & Mean & $\begin{array}{c}\mathrm{K}_{1} \\
(0 \mathrm{~kg} \\
\left.\mathrm{K} \mathrm{ha}^{-1}\right)\end{array}$ & $\begin{array}{c}\mathbf{K}_{2} \\
(100 \mathbf{~ k g} \\
\left.\mathrm{K} \mathrm{ha}^{-1}\right) \\
\end{array}$ & $\begin{array}{c}\mathrm{K}_{3} \\
(250 \mathrm{~kg} \\
\left.\mathrm{K} \mathrm{ha}^{-1}\right) \\
\end{array}$ & Mean \\
\hline $\operatorname{Mg}_{1}\left(0 \mathrm{~kg} \mathrm{Mg} \mathrm{ha}^{-1}\right)$ & 7.81 & 7.83 & 7.89 & 7.84 & 119.3 & 122.0 & 125.1 & 112.1 \\
\hline $\mathrm{Mg}_{2}\left(50 \mathrm{~kg} \mathrm{Mg} \mathrm{ha}^{-1}\right)$ & 7.68 & 7.72 & 7.81 & 7.74 & 114.4 & 118.6 & 120.8 & 118.0 \\
\hline $\mathrm{Mg}_{3}\left(100 \mathrm{~kg} \mathrm{Mg} \mathrm{ha}^{-1}\right)$ & 7.46 & 7.50 & 7.69 & 7.55 & 106.9 & 112.4 & 117.1 & 112.1 \\
\hline $\mathrm{Mg}_{4}\left(250 \mathrm{~kg} \mathrm{Mg} \mathrm{ha}^{-1}\right)$ & 7.34 & 7.41 & 7.63 & 7.46 & 101.8 & 105.9 & 111.5 & 106.4 \\
\hline \multirow[t]{2}{*}{ Mean } & 7.57 & 7.61 & 7.76 & & 110.6 & 114.7 & 118.6 & \\
\hline & \multicolumn{2}{|c|}{ S. Em \pm} & \multicolumn{2}{|c|}{ C.D at $5 \%$} & \multicolumn{2}{|c|}{ S. Em \pm} & \multicolumn{2}{|c|}{ C.D at $5 \%$} \\
\hline Mg & \multicolumn{2}{|c|}{$\mathbf{0 . 0 7 3}$} & \multicolumn{2}{|c|}{0.22} & \multicolumn{2}{|c|}{1.72} & \multicolumn{2}{|c|}{5.16} \\
\hline $\mathbf{K}$ & \multirow{2}{*}{\multicolumn{2}{|c|}{0.100}} & \multicolumn{2}{|c|}{0.30} & \multicolumn{2}{|c|}{2.09} & \multicolumn{2}{|c|}{6.26} \\
\hline $\operatorname{Mg} \times \mathbf{K}$ & & & \multicolumn{2}{|c|}{0.34} & \multicolumn{2}{|c|}{2.36} & \multicolumn{2}{|c|}{7.07} \\
\hline
\end{tabular}

Table.5 Interaction effects of applied $\mathrm{Mg}$ and $\mathrm{K}$ on soil calcium and soil magnesium

\begin{tabular}{|c|c|c|c|c|c|c|c|c|}
\hline \multirow[b]{2}{*}{ Treatment } & \multicolumn{4}{|c|}{ Soil Calcium (ppm) } & \multicolumn{4}{|c|}{ Soil Magnesium $\left(\mathrm{kg} \mathrm{ha}^{-1}\right)$} \\
\hline & $\begin{array}{c}\mathbf{K}_{1} \\
(0 \mathrm{~kg} \\
\left.\mathrm{K} \mathbf{h a}^{-1}\right) \\
\end{array}$ & $\begin{array}{c}\mathrm{K}_{2} \\
(100 \mathrm{~kg} \\
\left.\mathrm{K} \mathrm{ha}^{-1}\right) \\
\end{array}$ & $\begin{array}{c}\mathrm{K}_{3} \\
(250 \mathrm{~kg} \\
\left.\mathrm{K} \mathrm{ha}^{-1}\right)\end{array}$ & Mean & $\begin{array}{c}\mathbf{K}_{\mathbf{1}} \\
(0 \mathrm{~kg} \\
\left.\mathrm{K} \mathrm{ha}^{-1}\right) \\
\end{array}$ & $\begin{array}{c}\mathrm{K}_{2} \\
(100 \mathrm{~kg} \\
\left.\mathrm{K} \mathrm{ha}^{-1}\right) \\
\end{array}$ & $\begin{array}{c}\mathbf{K}_{3} \\
(250 \mathrm{~kg} \\
\left.\mathrm{K} \mathrm{ha}^{-1}\right) \\
\end{array}$ & Mean \\
\hline $\mathrm{Mg}_{1}\left(0 \mathrm{~kg} \mathrm{Mg} \mathrm{ha}{ }^{-1}\right)$ & 479.2 & 493.0 & 513.8 & 495.3 & 124.2 & 129.6 & 141.8 & 131.9 \\
\hline $\mathrm{Mg}_{2}\left(50 \mathrm{~kg} \mathrm{Mg} \mathrm{ha}^{-1}\right)$ & 451.6 & 466.4 & 475.1 & 464.4 & 169.8 & 185.7 & 197.6 & 184.4 \\
\hline $\operatorname{Mg}_{3}\left(100 \mathrm{~kg} \mathrm{Mg} \mathrm{ha}^{-1}\right)$ & 438.2 & 421.7 & 409.5 & 423.1 & 202.9 & 214.5 & 229.8 & 215.7 \\
\hline $\mathrm{Mg}_{4}\left(250 \mathrm{~kg} \mathrm{Mg} \mathrm{ha}^{-1}\right)$ & 406.3 & 398.5 & 380.4 & 395.1 & 227.1 & 241.8 & 263.6 & 244.2 \\
\hline \multirow[t]{2}{*}{ Mean } & 443.8 & 444.9 & 444.7 & & 181.0 & 192.9 & 208.1 & \\
\hline & \multicolumn{2}{|c|}{ S. Em \pm} & \multicolumn{2}{|c|}{ C.D at $5 \%$} & \multicolumn{2}{|c|}{ S. Em \pm} & \multicolumn{2}{|c|}{ C.D at $5 \%$} \\
\hline Mg & \multicolumn{2}{|c|}{09.8} & \multicolumn{2}{|c|}{29.36} & \multicolumn{2}{|c|}{6.34} & \multicolumn{2}{|c|}{19.00} \\
\hline $\mathbf{K}$ & \multicolumn{2}{|c|}{ NS } & \multicolumn{2}{|c|}{ NS } & \multicolumn{2}{|c|}{6.80} & \multicolumn{2}{|c|}{20.37} \\
\hline Mg x K & \multicolumn{2}{|c|}{12.1} & \multicolumn{2}{|c|}{36.2} & \multicolumn{2}{|c|}{8.36} & \multicolumn{2}{|c|}{25.04} \\
\hline
\end{tabular}

Fig.1 Effect of combined application of different levels of magnesium and potassium on soil $\mathrm{pH}$

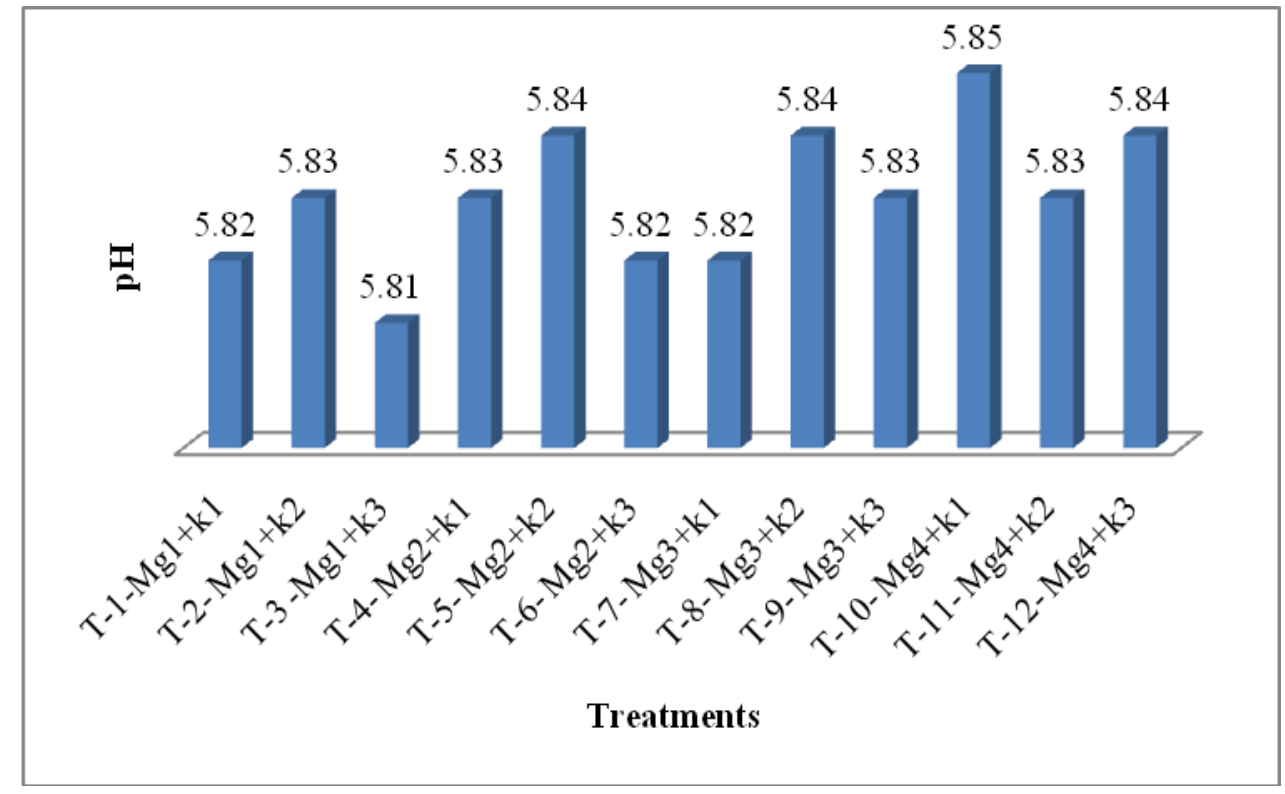


Fig.2 Effect of combined application of different levels of magnesium and potassium on soil EC

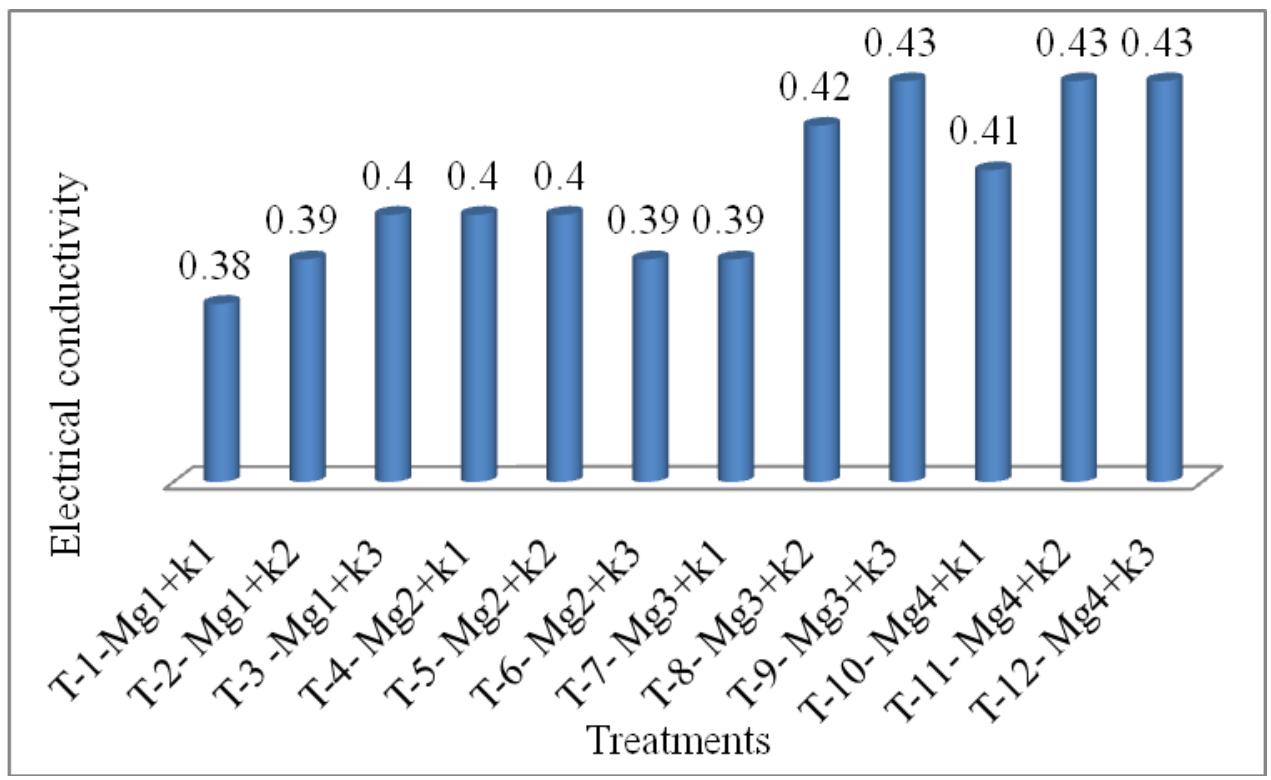

The lowest available $\mathrm{K}$ of $101.8 \mathrm{~kg} \mathrm{~K} \mathrm{ha}^{-1}$ was recorded when $\mathrm{Mg}_{4}\left(250 \mathrm{~kg} \mathrm{Mg} \mathrm{ha}{ }^{-1}\right)$ was combined with $\mathrm{K}_{1}\left(0 \mathrm{~kg} \mathrm{~K} \mathrm{ha}^{-1}\right)$. On the other hand, the highest available $\mathrm{K}$ of $125.1 \mathrm{~kg} \mathrm{~K}$ $\mathrm{ha}^{-1}$ was recorded at the combined application of $\mathrm{Mg}_{1}\left(0 \mathrm{~kg} \mathrm{Mg} \mathrm{ha}{ }^{-1}\right)$ with $\mathrm{K}_{3}\left(250 \mathrm{~kg} \mathrm{~K} \mathrm{ha}^{-1}\right)$. These results indicated an antagonism between $\mathrm{Mg}$ and $\mathrm{K}$ availability in the soil. When the level of $\mathrm{Mg}$ is increased then it will try to occupy exchangeable $\mathrm{K}$ from the soil surface and vice versa.

As reported by Ananthanarayana and Hanumantharaju (1992), antagonism between $\mathrm{Mg}$ and $\mathrm{K}$ could be due to differences in their ionic mobility. High $\mathrm{K}$ concentration in nutrient solution resulted in $\mathrm{Mg}$ deficiency in plant tissue (Jones, 1999) and vice-versa. Kirkbym and Mengel (1976) reported that high $\mathrm{Mg}$ concentration in soil or plant is due to poor status of $\mathrm{K}$ in soil. In Tomato, Sonneveld (1987) observed that, $\mathrm{Mg}$ deficiency symptoms reduced due to high and low $\mathrm{K} / \mathrm{Ca}$ elements in the nutrient solution. This suggests that cation interactions are more intense at high concentrations than at low ones (table 4).

\section{Soil Ca and Soil Mg}

In a nutrient uptake process, $\mathrm{K}, \mathrm{Mg}$ and $\mathrm{Ca}$ are strongly antagonistic. Similar to potassium, $\mathrm{Mg}$ also should have antagonistic relationship with $\mathrm{Ca}$ in the soil. However, no significant change in soil $\mathrm{Ca}$ was observed through the application of different combinations of $\mathrm{Mg}$ and $\mathrm{K}$. But the trend indicated that with an increase in the $\mathrm{Mg}$ levels the mean exchangeable $\mathrm{Ca}$ content decreased. As the level of applied $\mathrm{K}$ increased the exchangeable $\mathrm{Ca}$ content slightly increased. The combined application of $\mathrm{Mg}$ and $\mathrm{K}$ resulted in reduction of soil exchangeable $\mathrm{Ca}$ from $479.2 \mathrm{ppm}$ in $\mathrm{Mg}_{1}(0 \mathrm{~kg}$ $\left.\mathrm{Mg} \mathrm{ha}^{-1}\right)$ with $\mathrm{K}_{1}\left(0 \mathrm{~kg} \mathrm{~K} \mathrm{ha}^{-1}\right)$ to $380.4 \mathrm{ppm}$ in $\mathrm{Mg}_{4}\left(250 \mathrm{~kg} \mathrm{Mg} \mathrm{ha}{ }^{-1}\right)$ with $\mathrm{K}_{3}\left(250 \mathrm{~kg} \mathrm{~K} \mathrm{ha}^{-1}\right)$. At very high concentration, $\mathrm{Mg}^{2+}$ will suppress $\mathrm{K}^{+}$uptake at the exchange site.

A study by tomato magnesium nutrition by Brun (1984) suggested that a nutrient solution with a $(\mathrm{Ca}+\mathrm{Mg})$ : $\mathrm{K}$ ratio of 2.75 seems to be adequate for satisfactory tomato crop. The application of $\mathrm{Mg}$ and $\mathrm{K}$ significantly influenced the soil exchangeable $\mathrm{Mg}$ content. 
When the $\mathrm{Mg}$ levels increased the mean exchangeable $\mathrm{Mg}$ content also increased from $131.9 \mathrm{ppm}$ in control to $244.2 \mathrm{ppm}$ in $\mathrm{Mg}_{4}$ $\left(250 \mathrm{~kg} \mathrm{Mg} \mathrm{ha}^{-1}\right)$. As the level of applied $\mathrm{K}$ increased the exchangeable $\mathrm{Mg}$ content slightly increased from 181.0 to $208.1 \mathrm{ppm}$. Interaction effects of applied $\mathrm{Mg}$ and $\mathrm{K}$ resulted in higher soil exchangeable $\mathrm{Mg}$ from $124.2 \mathrm{ppm}$ in $\operatorname{Mg}_{1}\left(0 \mathrm{~kg} \mathrm{Mg} \mathrm{ha}{ }^{-1}\right)$ with $\mathrm{K}_{1}(0$ $\left.\mathrm{kg} \mathrm{K} \mathrm{ha}{ }^{-1}\right)$ to $263.6 \mathrm{ppm}$ in $\mathrm{Mg}_{4}(250 \mathrm{~kg} \mathrm{Mg}$ ha $^{-1}$ ) with $\mathrm{K}_{3}\left(250 \mathrm{~kg} \mathrm{~K} \mathrm{ha}^{-1}\right)$.

In a study on tomato correct ratio of $\mathrm{K}$ and $\mathrm{Mg}$ in the soil is important because of excessive concentrations of either element can negatively affect the plant growth (Bergmann, 1992). High K concentration in nutrient solution resulted in $\mathrm{Mg}$ deficiency in plant tissue (Jones, 1999) and vice-versa. Antagonism between $\mathrm{K}$ and $\mathrm{Mg}$ observed (Kolota and Orlowski, 1984) in tomato. Good plant growth and highest yields were obtained from the plants recurring $\mathrm{K}_{2} \mathrm{O}$ and $\mathrm{Mg}$ each at $400 \mathrm{Mg} \mathrm{l}^{-1}$ soil. Adams et al., (1978) studied tomato yield in relation to the $\mathrm{N}, \mathrm{K}$ and $\mathrm{Mg}$ status of the plants and of the peat substrate. Maximum yields were obtained when the nutrient content in leaves was $4.5-5.1$ per cent $\mathrm{N}$, 4.4-5.6 percent $\mathrm{K}$ and $0.31-0.40$ per cent $\mathrm{Mg}$. The results shows that interactions $\mathrm{K}, \mathrm{Ca}$ and $\mathrm{Mg}$ in a soil or nutrient media play each other antagonism in uptake of these elements by plants (Table 5).

The results of the above experiment shown that the important interactions of $\mathrm{K}, \mathrm{Ca}$ and $\mathrm{Mg}$ in the soil or nutrient media were antagonistic to each other in the uptake of these elements by plants. Similarly $\mathrm{Ca}$ and $\mathrm{Mg}, \mathrm{K}$ and $\mathrm{Mg}$ also have similar antagonistic relations with respect to their availability of one over the other and their effects on crop performance. This suggests that cation interactions are more intense at high concentrations than at low ones. The overall performance indicated that the application of
$\mathrm{Mg}$ increased the yield of tomato up to a quantity of $50 \mathrm{~kg} \mathrm{Mg} \mathrm{ha}{ }^{-1}$. It was also observed that, the yield of tomato increased at lower levels of applied $\mathrm{K}$ with $50 \mathrm{~kg}$ of $\mathrm{Mg}$ $\mathrm{ha}^{-1}$ and decreased at higher levels beyond 50 $\mathrm{kg} \mathrm{Mg} \mathrm{ha}{ }^{-1}$. Graded levels of $\mathrm{Mg}$ and $\mathrm{K}$ did not have any significant effect on either soil $\mathrm{pH}, \mathrm{EC}$ and $\mathrm{OC}$.

Besides it was found that, application of $\mathrm{Mg}$ and $\mathrm{K}$ did not have any significant influence on the soil available $\mathrm{N}$. An increase in the applied $\mathrm{Mg}$ levels has shown a reduction in the mean available $\mathrm{N}$ content. Further a synergistic reaction could be observed between $\mathrm{Mg}$ and $\mathrm{P}$ at lower levels of $\mathrm{Mg}$. The application of $\mathrm{Mg}$ and $\mathrm{K}$ together had significant negative influence on soil available $\mathrm{K}$ and $\mathrm{Ca}$. The mean available $\mathrm{K}$ content decreased with an increase in the level of $\mathrm{Mg}$. These results clearly indicated the existence of antagonism between $\mathrm{Mg}$ and $\mathrm{K}$ and $\mathrm{Ca}$ in the soil. Interaction was also negative between $\mathrm{Mg}$ and $\mathrm{K}$ only at higher levels of $\mathrm{Mg}$ and $\mathrm{K}$ and at lower levels it was synergistic. Thus, it was concluded that for the soil which is deficient in $\mathrm{K}$ and $\mathrm{Mg}$, the deficiency of $\mathrm{Mg}$ should be corrected before applying $\mathrm{K}$ fertilizer for achieving desirable yields in tomato.

\section{References}

Adams, P., 1991. Effects of increasing the salinity of the nutrient solution with major nutrients or sodium chloride on the yield, quality and composition of tomatoes grown in rockwool. J. Hort. Sci., 66: 201-207.

Adams, P., Davies, J.N. and Winsor, G.W. 1978. Effects of nitrogen, potassium and magnesium on the quality and chemical composition of tomatoes grown in peat. $J$. Hort. Sci., 53:115-122.

Ananthanarayana, R., and Hanumantharaju, T.H. 1992. Interactions of $\mathrm{Ca}$ and $\mathrm{Mg}$ with other plant nutrients. In: H.L.S Tandon (Ed).

Ananthanarayana, R., and Venkatarao, B.V. 1979. Studies on Dynamic of Magnesium in soils 
and crops of Karnataka.Mysore $J$. Agric.Sci., 13:416-419.

Bergmann, W., 1992. Nutritional Disorders of plants development, visual and analytical diagnosis. Gustav Fisher Verlag, Jena, Germany.

Brun, R., 1984. Study of tomato magnesium nutrition effects on the absorption of other major elementsts, on plant composition, on yield and on fruit composition (French) VI international colloquium for the optimization of plant nutrition proceeding vol.3: 779-786.

Foy, C.D., and Barber, S.A.1958. Magnesium deficiency and Corn yield on two acids Indiana soils. Soil Sci.Soc. Amer.Proc, 22: 145-148.

Ganeshamurthy, A.N., and Hegde, D.M. 1980. Soil Health and Nutritional Security Secondary Nutrients, Indian Society of Soil Science Platinum Jubilee SymposiumProceedings, pp: 1-20.

Gough, C., and Hobson, G.E. 1990. A comparison of the productivity, quality, shelf-life characteristics and consumer reaction to the crop from cherry tomato plants grown at different levels of salinity. J. Hort. Sci., 65:125-134.

Grienrson, D., and Kader, A.A.1986.Fruit ripening and quality of tomato crop. Chapman and Hall, London. pp: 240-280.

Hao, X., and Papadopoulos, A.P. 2003. Effect of calcium and magnesium in growth, fruit yield and quality in a full greenhouse tomato crop grown on rockwool. Candian J. Plant Sci., 83: 903-972.

Hohlt, H.E., and Maynard, D.N.1966. Magnesium nutrition of spinach. Proc. Amer. Soc. Hort. Sci., 89:478-482
Jones, J.B., 1999. Tomato plant culture: In the field, greenhouse, and home garden. CRC Press LLC, Florida. pp: 11-53.

Kirkbym, E.A., and Mengel, K.1976. The role of magnesium in plant nutrition. Pflanzenerth. U. Bodenkde. 2: 209-222.

Kolota, E., and Orlwski, M.1984. The influence of potassium and magnesium fertilization on growth yield and mineral nutrition of greenhouse tomatoes Biuletyn Warzywniczy 27: 301-315.

Mizrahi and Mizrahi, Y. 1982. Effect of salinity on tomato fruit ripening. Plant Physiol., 69:970-996.

Nambiar, K.K.M., and Abrol, I.P.1989. Long term fertilizer experiments in India: An overview Fertilizers News, 34 (4) : 11-26.

NHB, 2014. All India Area, Production and productivity of Tomato, Indian Hort.Data base

Shukla, A.K., Dwivedi, B.S., Singh, V.K. and Gill, M.S. 2009. Macro role of micronutrients. Indian J. Fert., 5:11-30.

Sonneveld, C., 1987. Magnesium deficiency in rockwool-grown tomatoes as affected by climatic conditions and plant nutrition. $J$. Plant Nutr, 10(9-16): 1591-1604.

Subramanian, R.M., Manickam, T.S. and Krishnamoorthy, K.K. 1976. Studies on the effect of magnesium on the yield and quality of groundnut (vol 1) on two red soils of Tamil Nadu. Madras Agril. J., 63:81-84.

Sundaraja, N., Nagaraju, M.N. Venkataramu and Jaganath, M.K. 1972. Design and analysis of field experiments, U.A.S., Bangalore.

Ward, G.M., and Miller, M.J. 1969. Magnesium deficiency in greenhouse tomatoes. Can. $J$. Plant Sci., 49:53-59.

\section{How to cite this article:}

Kasinath, B.L., A.N. Ganeshmurthy, T. Senthivel, M. Senthil Kumar, B.L. Manjunath and Sadashiva, A.T. 2017. Studies on Interaction Effects of Combined Application of Magnesium and Potassium on Soil Properties and Yield of Tomato (Solanum lycopersicum L.) In an Alfisol. Int.J.Curr.Microbiol.App.Sci. 6(9): 2775-2784.

doi: https://doi.org/10.20546/ijcmas.2017.609.342 